\title{
RNA clubs
}

\section{KEVIN M. WEEKS}

Department of Chemistry, University of North Carolina, Chapel Hill, North Carolina 27599-3290, USA

When I started graduate school in 1987, my knowledge of RNA was probably typical of that of most chemistry graduate students, meaning it was pretty minimal. I took my first (and only) biochemistry class in Germany, at a time when my German was just barely up to the challenge. RNA was hardly mentioned, but I do recall learning that one of the activities of the ribosome was "peptidyl transferase." As I was thinking about starting my $\mathrm{PhD}$ project, I was intrigued by my advisor's very general suggestion that "maybe it was time to work on RNA again." My advisor, Don Crothers, had done pioneering work on RNA thermodynamics and structure in the 1970s, focusing on both the energetics of base pairing and on folding by tRNAs. A decade later, he convinced Karen LeCuyer and me to reintroduce RNA into the lab. I was motivated in part by exciting new work that suggested that viruses used RNA structures as part of their replication strategies, specifically by the hypothesis that the tRNA-like structures found at the ends of many viral RNA genomes constituted a kind of "molecular fossil" and by the very recent discovery that one of the most important features of HIV was the TAR stem-loop element that enabled "transactivation" of the virus by the Tat protein.

Karen and I received endless assistance from neighboring labs in getting our experiments going, in learning how to perform the then-brand-new method of in vitro transcription using T7 RNA polymerase, and in learning the lore of working with and preventing the degradation of RNA. In hindsight, some of the information passed on to us regarding working with RNA was apocryphal, but we took it very seriously, especially because we were working in what was mostly a DNA lab, where members routinely performed many cloning and miniprep steps and weighed out common reagents using ungloved hands! Throughout this process, I was motivated by exciting work being done at other Yale labs on RNA and by the special comradery among graduate students and postdocs in these labs, a de facto RNA Club.

In the late 1980s, when I first began to have the opportunity to present my work in posters and short talks, I also enjoyed the seeming instant interactions among groups who

Corresponding author: weeks@unc.edu

Article and publication date are at http://www.rnajournal.org/cgi/doi/10. $1261 /$ rna.050476.115. Freely available online through the RNA Open Access option. had chosen to view their work in an RNA-centric way. From those days, I can recall with real clarity the times when senior scientists spent a bit of time at my poster or asked me questions either during or after a talk. These interactions made me think that my work was special and potentially important. Recalling these interactions continues to motivate me to interact fully with poster presenters and young scientist speakers now. I am sure that these kinds of interactions occur in many scientific fields, but, to me, they are another kind of Special RNA Club.

Like many practicing scientists, I have fond memories of my postdoctoral years. At the University of Colorado, I was exposed to my first Official RNA Club. Lore has it that this was the brainchild of Olke Uhlenbeck. RNA Club was held in the evenings, was attended by senior faculty, and was a great opportunity to learn broadly what was possible in RNA science. At the time, my wife Cyndy and I had two young daughters, and Cyndy was launching her own stimulating and demanding career. Likely imperfectly, I tried to minimize evening commitments that made it harder for our family to work smoothly together. RNA Club met the stringent criteria of being worth working around.

Now as a professor, as it was when I was a graduate student and a postdoc, RNA science seems ever exciting and new. I think everyone in the field takes special pride in the amazing diversity and number of Nobel prizes that have been awarded for RNA-centric discoveries. Nobel prizes are important for many reasons but, for me, their greatest role is to remind everyone that-in addition to athletes, rock stars, and eccentric billionaires-science transforms our understanding of the world and is worthy of special recognition in the popular media. Over my career, eight Nobel prizes have been awarded for RNA or closely related science: RNA catalysis (1989), splicing (1993), PCR (1993), RNAi (2006), transcription (2006), HIV/AIDS (2008), telomeres and telomerase (2009), and the ribosome (2009). There is much emerging work that merits consideration for Nobel recognition. The individual winners of these awards are deservedly in a special RNA Club. But more broadly, I enjoy being a part of the RNA Club that celebrates these scientific achievements, and

(C) 2015 Weeks This article, published in RNA, is available under a Creative Commons License (Attribution-NonCommercial 4.0 International), as described at http://creativecommons.org/licenses/by-nc/4.0/. 
hopefully shares and conveys these achievements to neighbors, colleagues, friends, and family.

The Research Triangle Park area in North Carolina has become a center of RNA science. We have a vigorous RNA Club hosted by UNC and Duke and that attracts student and senior scientists from these two universities, and from North Carolina State and the NIEHS (a branch of the NIH). The Research Triangle Park is host to numerous biotech companies with RNA-centric projects and products, spanning twoperson startups to large biopharmaceutical companies. Many individuals move to this area for training, become fond of its great science and quality of life, and become part of the RNA Club That Stays Here. Every second year, we host an "RNA Tool and Target" conference that blends basic science and translational innovations and that fuels ideas for Future RNA Clubs.

It has been a privilege to be part of these diverse, unique, and complementary RNA Clubs. I am going to stick with these clubs because RNA is still A Next Cool Thing. 

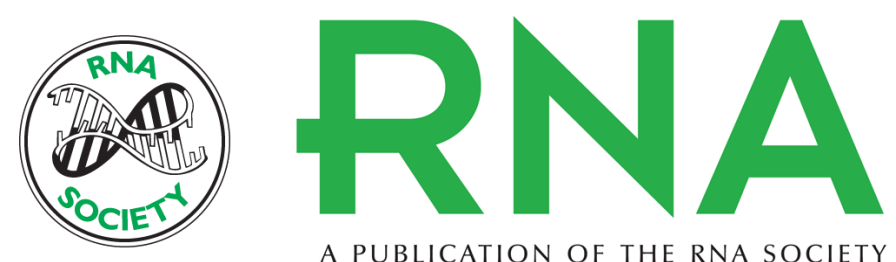

A PUBLICATION OF THE RNA SOCIETY

\section{RNA clubs}

Kevin M. Weeks

RNA 2015 21: 760-761

Open Access Freely available online through the RNA Open Access option.

Creative This article, published in RNA, is available under a Creative Commons License Commons (Attribution-NonCommercial 4.0 International), as described at License http://creativecommons.org/licenses/by-nc/4.0/.

Email Alerting Receive free email alerts when new articles cite this article - sign up in the box at the Service top right corner of the article or click here. 